\title{
VARIABILITY IN FIRE PRESCRIPTIONS TO PROMOTE WILDLIFE FOODS IN THE LONGLEAF PINE ECOSYSTEM
}

\section{Marcus A. Lashley ${ }^{*}$, M. Colter Chitwood ${ }^{2}$, Craig A. Harper ${ }^{3}$, Christopher S. DePerno $^{2}$, and Christopher E. Moorman ${ }^{2}$}

${ }^{1}$ Department of Wildlife, Fisheries, and Aquaculture, Mississippi State University, Box 9690, Mississippi State, Mississippi 39762, USA

${ }^{2}$ Department of Forestry and Environmental Resources, Fisheries, Wildlife, and Conservation Biology, North Carolina State University, 110 Brooks Avenue, Raleigh, North Carolina 27607, USA

${ }^{3}$ Department of Forestry, Wildlife, and Fisheries, University of Tennessee, 2431 Joe Johnson Drive, Knoxville, Tennessee 37996, USA

*Corresponding author: Tel.: +1-662-325-5795; e-mail: marcus.lashley@msstate.edu

\section{ABSTRACT}

Prescribed fire is commonly used to restore and maintain the longleaf pine (Pinus palustris Mill.) ecosystem (LLPE). A key function of the LLPE is the provisioning of food for wildlife. Despite the plethora of literature evaluating the effects of fire season and fire-return interval on plant community dynamics, little attention has been given to the response of wildlife foods to fire season or fire-return interval. We measured the availability of key wildlife foods (fleshy fruit [i.e., seed containing a nutritious pericarp] and understory plant biomass) in upland pine forest following dormant-season (December-February) and growing-season (April-June) fires in a chronosequential design. Also, we quantified the relative contributions of the upland hardwood and bottomland hardwood forest types, which often are intentionally suppressed in the LLPE. In 2011 and 2012, we measured understory leafy biomass,

\section{RESUMEN}

Las quemas prescriptas son comúnmente usadas para restaurar y mantener el ecosistema de pino palustre o pino de hoja larga (Pinus palustris Mill.), comúnmente llamado LLPE. Una función clave del LLPE es el aprovisionamiento de alimento para la fauna silvestre. A pesar de la profusa literatura que evalúa los efectos de la estación de fuego y el intervalo en la recurrencia del fuego en la dinámica de las comunidades vegetales, muy poca atención ha sido brindada a la respuesta de los alimentos para la fauna a la estación de fuego o a la recurrencia entre fuegos. Nosotros medimos la disponibilidad de alimentos clave para la fauna (aquellos frutos carnosos [i.e., semillas que contienen un pericarpio nutritivo] y plantas del sotobosque) en un bosque de altura de pino después de fuegos ocurridos en períodos de latencia (diciembre-febrero) y de crecimiento activo (abril-junio) en base a un diseño crono-secuencial. También cuantificamos las contribuciones relativas de los bosques altos y bajos de latifoliadas, que frecuentemente son intencionalmente suprimidos en los LLPE. En 2011 y 2012, medimos la biomasa foliar del sotobosque, la bio- 
biomass of forages selected by whitetailed deer (Odocoileus virginianus Zimm.), and soft mast production chronosequentially in relation to years-since-fire, fire season, and vegetation type in the LLPE at Fort Bragg Military Installation, North Carolina, USA. Understory leafy biomass increased in upland pine and hardwood forests as years-since-fire increased until two years post fire. Selected forages decreased in upland pine forest and increased in upland hardwood forest as time-since-fire increased. In upland pine forests burned during the growing season, $94 \%$ of the fruit was detected two years after fire, $6 \%$ one year after fire, and $0 \%$ the same year as fire. In June, fruit density was greatest in bottomland hardwood forest; in July, fruit density was greatest in dormant-season burned upland pine forest; in August, fruit density was greatest in upland hardwood forest; and in September, fruit density was greatest in upland hardwood and bottomland hardwood forest. Overall summer fruit density (i.e., the sum of fruit density detected each month) was greatest in upland hardwood forest. Understory leafy biomass and deer-selected forages were stable in bottomland hardwood forest because they were not burned, thereby providing a relatively high and stable availability from year to year. Our data demonstrate the importance of diversity in fire season and frequency, and diversity in vegetation types to promote key wildlife foods in the LLPE. masa de los forrajes seleccionados por el ciervo de cola blanca (Odocoileus virginianus Zimm.), y la producción de frutos blandos de arbustos, de manera crono-secuencial, en relación a los años desde el fuego, la estación de fuego, y el tipo de vegetación en el ecosistema LLPE ubicado en el Fort Bragg Military Installation, Carolina del Norte, EEUU. La biomasa foliar del sotobosque se incrementó en el bosque alto y en los bosques de latifoliadas a medida que el tiempo del post-fuego se incrementó hasta los dos años posteriores al fuego. Los forrajes seleccionados disminuyeron en el bosque alto de pino y se incrementaron en el bosque alto de latifoliadas a medida que se incrementó el tiempo después del fuego. En los bosques altos de pino quemados durante la estación de crecimiento, $94 \%$ de los frutos fueron detectados dos años después el fuego, $6 \%$ un año después del fuego, y $0 \%$ en el mismo año del evento de fuego. En junio, la densidad de frutos fue mayor en los bosques bajos de latifoliadas; en julio, la densidad de frutos fue mayor en el período latente en el bosque de pino de altura; en agosto, la densidad de frutos fue mayor en los bosques altos de latifoliadas; y en septiembre, la densidad de frutos fue mayor tanto en los bosques altos como bajos de latifoliadas. Considerando todo el verano, la densidad de frutos (i.e., la suma de la densidad de frutos detectada cada mes) fue mayor en los bosques altos de latifoliadas. La biomasa foliar del sotobosque y el forraje seleccionado por el ciervo de cola blanca fue estable en el sotobosque del bosque bajo de latifoliadas, dado que éste no fue quemado, proveyendo por lo tanto de una disponibilidad alta y estable año tras año. Nuestros datos muestran la importancia de la diversidad en la estación y frecuencia de los fuegos y la diversidad en los tipos de vegetación para promover alimentos clave para la fauna en los ecosistemas LLPE. 
Keywords: biodiversity, diet selection, ecosystem-based management, fire application, fire frequency, fire season, fruit, heterogeneity, microhistological survey, white-tailed deer

Citation: Lashley, M.A., M.C. Chitwood, C.A. Harper, C.S. DePerno, and C.E. Moorman. 2015. Variability in fire prescriptions to promote wildlife foods in the longleaf pine ecosystem. Fire Ecology 11(3): 62-79. doi: 10.4996/fireecology.1103062

\section{INTRODUCTION}

In the US, the highly threatened longleaf pine (Pinus palustris Mill.) ecosystem (LLPE) is commonly targeted for ecological restoration (Landers et al. 1995, Brockway et al. 2005, Fill et al. 2012). Historically, the LLPE was one of the most extensive ecosystems in North America and occupied 38 million ha in the southeastern United States (Frost 1993, Landers et al. 1995). Currently, $\sim 800000$ ha remain, representing a $97 \%$ decline across the natural range (Frost 2006). Restoring the LLPE may provide several ecosystem services, including improved habitat quality for wildlife, high-quality longleaf pine timber and pine straw, recreational opportunities, and preservation of natural and cultural legacies (Brockway et al. 2005).

Previous studies suggested developing prescribed fire regimes based on various types of data for the LLPE (e.g., modeling [Beckage et al. 2005], historical fire scars [Stambaugh et al. 2011], plant reproductive allocations [Fill et al. 2012]). The consensus is that high-frequency growing-season fire regimes $(\leq 3 \mathrm{yr}$ fire-return interval in May or June; Waldrop et al. 1992, Streng et al. 1993, Stambaugh et al. 2011, Fill et al. 2012) are keystone processes and vital to restoring the LLPE (Aschenbach et al. 2010). However, the LLPE represents one of the most diverse systems in the temperate zone, and simplified management strategies guided by a few focal flora and fauna may fail to accurately represent the complexity within this dynamic ecosystem (Franklin 1993, Drew et al. 1998). For example, Lashley et al. (2014a) reported that homogeneous fire applications could simplify forest stand structure and landscape floral composition even when prescriptions are based on historical references. Similarly, Beckage et al. (2005) raised concern for oversimplified inferences of reference conditions in fire-maintained ecosystems. Because fire frequency, intensity, and seasonality may affect flora and fauna differently (Van Lear and Harlow 2000), variable fire prescriptions are likely needed to create and maintain a heterogeneous landscape (Fuhlendorf and Engle 2001, Bond and Archibald 2003, Fuhlendorf et al. 2006).

Previous study of the effects of fire season and frequency on understory flora and related forest structural characteristics in the LLPE showed that variability in fire prescriptions was needed to maximize biodiversity and ecosystem function with fire (Hiers et al. 2000, Palik et al. 2002, Ryan et al. 2013). For example, Fill et al. (2012) reported reproductive responses of wiregrass (Aristida stricta Michx.) were greatest following early growing-season fires (May to June). Furthermore, Clewell (1989) reported that wiregrass plants persist for extended periods without fire. Hence, wiregrass reproductive responses indicate adaptations to frequent growing-season fires, yet other characteristics of wiregrass simultaneously indicate adaptations to infrequent growing-season fire. Similarly, Ostertag and Menges (1994) reported that shrub species had differing reproductive allocation strategies to time-since-fire, and believed that plants likely did not synchronize strategies because of variability in historical fire-return intervals. Hiers et al. (2000) reported that fire season did not affect pollination and reproductive allocations of legumes in the LLPE; however, Platt et al. (1988) reported that the season of fire was im- 
portant in flowering synchrony in many forb species. Also, legumes in the LLPE respond similarly to fire suppression and dormant- and growing-season fires in terms of nitrogen fixation (Hiers et al. 2003). However, fire frequency may be of particular importance to the species composition in the understory, with yearly and biennial fires favoring herbaceous plants, and longer rotations allowing woody plants to establish (Glitzenstein et al. 2003).

Despite the plethora of literature concerning the application of fire in LLPE and the effects on floral diversity, reproductive allocations, and plant community structure, we were able to find only one study reporting on fleshy fruit (i.e., seed containing a nutritious pericarp; e.g., berry, drupe, etc.) production (Greenberg et al. 2012) and no studies reporting on leafy biomass or forage production for white-tailed deer (Odocoileus virginianus Zimm.; hereafter deer), the native keystone herbivore (Cote et al. 2004) in the LLPE. Further, Greenberg et al. (2012) did not relate fleshy fruit production to fire. Moreover, the relative contributions of vegetation types to the abundance of these foods in the LLPE are unknown. Fleshy fruit and leafy biomass are important to many fauna inhabiting the LLPE. While wildlife are essential components of ecosystem function and commonly considered in management plans, little information about the interactions of these food sources with fire season and frequency exists. Therefore, we measured overall understory leafy biomass, biomass of selected deer forages, and fleshy fruit production in relation to years-since-fire, fire season, and vegetation type. We hypothesized that the wildlife foods that we measured would respond differently to different fire seasons and frequencies, thus illustrating the importance of variability in fire regimes for promoting wildlife foods throughout the year in the LLPE.

\section{METHODS}

\section{Study Area}

We sampled leafy biomass and fruit density at Fort Bragg Military Installation (Fort Bragg) in Cumberland, Harnett, Hoke, and Moore counties, North Carolina, USA ( $35^{\circ} 6^{\prime}$ $\left.\mathrm{N}, 79^{\circ} 12^{\prime} \mathrm{W}\right)$. The 73469 ha property was located in the Sandhills physiographic region in the northernmost remnants of the LLPE. The long-term ( $\sim 50$ years) average yearly rainfall was $120 \mathrm{~cm}$, average yearly snowfall was 7.5 $\mathrm{cm}$, and there were $\sim 175$ frost-free days per year (Sorrie et al. 2006). According to the State Climate Office of North Carolina, there was a moderate drought in 2011 followed by a normal rainfall year in 2012. Primary vegetation types included longleaf pine, upland hardwoods, bottomland hardwoods, and managed openings (see Sorrie et al. 2006 for detailed floristic accounts). Fort Bragg Military Installation was considered an important contributor to the floristic diversity of the LLPE with more than 1200 plant species, 61 of which were species of conservation concern and 3 of which were federally endangered (Sorrie et al. 2006).

The LLPE is inhabited by numerous wildlife species that rely on vegetative plant parts or fleshy fruits for part or all of their diet. For example, deer, eastern cottontail (Sylvilagus floridanus Allen), Virginia opossum (Didelphis virginiana Kerr), gray fox (Urocyon cinereoargenteus Schreber), and raccoon (Procyon lotor L.) occur in the LLPE and consume plant parts or fleshy fruits. Similarly, numerous birds, including small passerines (e.g., American robin [Turdus migratorius L.], cedar waxwing [Bombycilla cedrorum Vieillot], hermit thrush [Catharus guttatus Pallas], gray catbird [Dumetella carolinensis L.]) and larger gallinaceous birds (e.g., wild turkey [Meleagris gallopavo L.], northern bobwhite [Colinus virginianus L.]), use fruits or plant parts in their diet. Also, at least two species of conservation concern (gopher tortoise [Gopherus poly- 
phemus Daudin] and Florida black bear [Ursus americanus floridanus Pallas]) rely heavily on the these food items in the LLPE.

Since 1989, the United States Department of Defense has managed burn units on a $3 \mathrm{yr}$ growing-season (April to June) fire-return interval, targeting the prevailing longleaf pine vegetation type (Cantrell et al. 1995). However, upland hardwood and bottomland hardwood stands are interspersed within some burn units and are subjected to the same fire regime, although fire behavior may differ based on moisture and fuels. The fire regime was initiated to maintain structural requirements for the federally endangered red-cockaded woodpecker (Picoides borealis Vieillot) and to maximize biodiversity of the LLPE (Cantrell et al. 1995). Because of limitations in resources, manpower, and adequate fire weather, some units not burned as scheduled were burned the following dormant season (January to February). However, these units were moved immediately back into the $3 \mathrm{yr}$ growing-season fire-return interval. Further, some units were exclusively burned on a dormant-season fire schedule to buffer sensitive areas such as buildings and other man-made structures on the base.

\section{Stand Selection}

We characterized three major vegetation types using a geographic information system (GIS) overlay map of land cover and firebreaks provided by the US Department of Defense: upland hardwood, bottomland hardwood, and upland pine. We characterized upland hardwood as any upland forest stand dominated by hardwood species (primarily turkey oak, Quercus laevis Walt.), bottomland hardwood as hardwood-dominated forest (primarily blackgum, Nyssa sylvatica biflora Marsh.) associated with streams, and upland pine as upland longleaf pine-dominated forest. We selected 5 or more representative units in each vegetation type across three separate drainages at Fort Bragg (averaging $7 \mathrm{~km}$ apart) to compare the relative contribution of each vegetation type to forage and fruit density. We selected units with similar soil types (Candor Sands complex) and basal area in upland pine and upland hardwood to reduce any biases that could be associated with soil productivity or overstory coverage. After controlling for soil type and basal area $\left(45 \mathrm{~m}^{2} \mathrm{ha}^{-1}\right.$ to $\left.60 \mathrm{~m}^{2} \mathrm{ha}^{-1}\right)$, we selected upland pine units based on the fire season (i.e., dormant- or growing-season fires; hereafter, dormant upland pine and growing upland pine, respectively) and years-since-fire (0 yr, 1 yr, 2 yr, 3 yr). We selected upland hardwood stands by years-since-fire $(0 \mathrm{yr}, 1 \mathrm{yr}$, $2 \mathrm{yr}, 3 \mathrm{yr})$. Units were selected for dormant upland pine or growing upland pine only if they had been burned in the respective season for three or more consecutive fire rotations (average 3.2 consecutive rotations for dormant upland pine and 5 rotations for growing upland pine). Dormant-season fires occurred from December to February and growing-season fires occurred April to June.

\section{Understory Leafy Biomass}

We had two objectives when measuring understory leafy biomass: 1) compare biomass among vegetation types within years-sincefire, and 2) compare biomass among yearssince-fire within each vegetation type. Therefore, in January to March 2011 (i.e., in the dormant season), we randomly placed $401.2 \mathrm{~m} \times$ $1.2 \mathrm{~m} \times 1.2 \mathrm{~m}$ woven-wire-panel exclusion cages in upland hardwood, dormant upland pine, and growing upland pine burned $0 \mathrm{yr}$ to 3 yr prior (i.e., 10 cages in each year-since-fire category for each vegetation type). Also, we placed 40 cages in bottomland hardwood units. Cages, designed to exclude herbivores, were used only to control for biases in understory biomass estimates related to herbivory. For example, if caged plots had the same biomass as random uncaged plots, then herbivory was not affecting understory biomass and all plots 
could be pooled for assessing understory biomass response to fire application. Cages were simply used as a precaution because deer may affect plant communities negatively at high densities (Cote et al. 2004). We did not expect deer at Fort Bragg to negatively affect the plant community because deer density decreased by as much as $60 \%$ from what was apparently sustained in the 1980s (Lashley et al. $2015 a$ ), which likely resulted from high predation rates from coyotes (Canis latrans Say) on adult and neonatal deer (Chitwood et al. 2014, 2015a, 2015b). From 1 to 14 August 2011, we collected all leafy biomass (i.e., standing crop) from woody species and entire herbaceous plants (excluding fibrous stems) within cages. Additionally, we sampled an uncaged plot at a randomly generated distance $(10 \mathrm{~m}$ to $100 \mathrm{~m})$ and bearing ( 0 degrees to 360 degrees) from the original location of the cage. The uncaged plot was kept in the same vegetation type with the same years-since-fire; we replaced the cages in a new area and repeated the sampling protocol in 2012 (i.e., 160 caged and 160 uncaged plots per year; Lashley et al. 2011). We separated samples by species, bagged them in small paper bags, and dried them in an air-flow dryer at $50^{\circ} \mathrm{C}$ (Lashley et al. 2014b). We weighed dried samples to the nearest 0.01 gram and calculated understory leafy biomass per hectare by summing plant weights from a plot and extrapolating to kilograms per hectare. The caged and uncaged plots served as the experimental unit for subsequent statistical analyses.

To measure the availability of selected deer forages, we first determined what flora were selected by deer on site. To do so, we calculated a selection index (Chesson 1978, 1983), which provided criteria for determining the strength of deer selection of a plant and an index cutoff value that represents the point at which deer are selecting the forage more than available. The Chesson index requires a measure of plant use by the targeted herbivore. Therefore, we collected deer fecal samples from May to August in 2011 and 2012 across Fort Bragg to perform a microhistological survey, which gives the proportion of each plant species in the diet based on the remaining undigested plant cells excreted in the feces (Vavra and Holechek 1980). Because one of the years was a drought, we calculated diet selection in each year separately to avoid biases in diet selection associated with drought (Lashley and Harper 2012). We collected at least five fecal samples per week consisting of at least 10 pellets per sample from 15 May to August in 2011 and 2012, and formed weekly composite samples $($ mean $=12.2$ fecal samples per composite sample for 30 composite samples). To ensure that samples were independent of one another, no two samples were collected within $1 \mathrm{~km}$ (greater than the average summer home range of adult female deer on the area; Lashley et al. $2015 b$ ) of each other during the respective week. The density of deer at Fort Bragg was very low $\left(3 \mathrm{~km}^{-1}\right.$ to $5 \mathrm{~km}^{-1}$, Lashley et al. 2015a), making collection of fecal samples difficult; therefore, we did not stratify fecal samples by vegetation type or years-since-fire. However, because deer are a relatively mobile species, the fecal sample may consist of dietary choices from the past several days. As each of the areas were readily available to deer (Lashley et al. 2015b), we did not suspect any bias in dietary choice associated with the area in which the fecal sample was found. Because plant species may be digested differently by deer, we used acid detergent fiber (ADF), which is a measure of indigestible fibers in plants, to standardize use based on the proportion of the plant that remains distinguishable in the microhistological survey (Vavra and Holechek 1980). Simultaneously, we collected samples of plants (72 genera) representing the plant-part selectivity of deer, and dried and submitted them to a National Forage Testing Association certified laboratory to determine the acid detergent fiber of each plant during each month that fecal samples were collected (Lashley et al. 2014b). After receiving diet 
compositions for each composite fecal sample, we weighted each plant-use percentage by the respective ADF to correct for differential digestibility of plants (Leslie et al. 1983). After correcting for differential digestibility, we calculated deer diet selection from the corrected use and availability (leafy biomass of each plant available on site). After determining which plants were selected, we calculated forage availability of selected forages from the collected leafy biomass estimates.

\section{Fruit Density}

We placed 30 25-meter transects in dormant upland pine, growing upland pine, upland hardwood, and bottomland hardwood units in each of four months (June to September) of 2011 and $2012\left(n=480 \mathrm{yr}^{-1}\right)$. After sampling of each transect in each month, the transect was moved in the next month to another area within the same vegetation type and years-since-fire when applicable. In growing upland pine, 10 of the transects each month were placed in areas $0 \mathrm{yr}, 1 \mathrm{yr}$, and $2 \mathrm{yr}$ since fire. We used the fruit-count method described in Lashley et al. (2014c) to measure understory fruit density under $1.2 \mathrm{~m}$ height (i.e., understory fruits) and within $0.5 \mathrm{~m}$ of each side along a $25 \mathrm{~m}$ transect. Fruits were tallied by species, month, vegetation type, and year, with the transect being the experimental unit in subsequent analyses. We extrapolated each transect fruit count into a per-hectare equivalent. We compared monthly fruit density over two growing seasons among vegetation types and time-since-fire (in growing upland pine only).

\section{Statistical Analyses}

Initially, we used analysis of variance to compare understory leafy biomass estimates between caged and uncaged plots to determine whether herbivory affected biomass. We used generalized linear regression, fitting the data with a Poisson distribution (to account for left truncation), to compare understory leafy biomass (total and deer-selected forages) among vegetation types with years-since-fire held constant. We used the same analysis to test for the effects of years-since-fire within a vegetation type. We assigned the year of collection and the drainage of the unit sampled as random effects to account for any site-specific or year-specific effects. Also, we used generalized linear regression to compare understory fruit density among vegetation types across months with year as a random effect and among the three categories of years-since-fire in growing upland pine with month and year as random effects. We fit the fruit data with a zero inflated Poisson distribution to account for left truncation and zero inflation. We used JMP 10.0 (SAS Corp., Cary, North Carolina, USA) for all analyses.

\section{RESULTS}

We detected 66 genera of native plants during the study, 33 of which were selected by deer and 6 of which produced fruits detected in the understory (Table 1). Ten genera accounted for the majority of the biomass (i.e., $\sim 80 \%$ ), with Aristida ( $34 \%)$ and Quercus ( $\sim 20 \%$ ) accounting for more than $50 \%$ of the biomass detected (Table 1). Understory leafy biomass was not affected by herbivory $(P=$ 0.99 ), so we combined caged and uncaged samples for subsequent analyses.

\section{Leafy Biomass}

Understory leafy biomass differed among the vegetation types, with biomass greatest in bottomland hardwood. Also, biomass was greater in upland pine than upland hardwood when holding years-since-fire constant (Table 2 ). Understory leafy biomass was greater $2 \mathrm{yr}$ and $3 \mathrm{yr}$ post fire than soon after fire (Table 2, Figure 1). Deer-selected forages were most available in bottomland hardwoods. Also, selected biomass was greater in upland hard- 
Table 1. Genera detected at Fort Bragg Military Installation, North Carolina, USA, from 2011 to 2012.

\begin{tabular}{|c|c|c|c|}
\hline Genus & Selected forages & Genus & Selected forages \\
\hline Acer $\mathrm{L}$. & $\mathrm{X}$ & Geranium L. & $\mathrm{X}$ \\
\hline Achillea L. & & Helianthus L. & $\mathrm{X}$ \\
\hline Alnus L. & & Hypericum L. & \\
\hline Ambrosia L. & & Ilex L. ${ }^{\mathrm{a}, \mathrm{c}}$ & \\
\hline Andropogon L. ${ }^{\mathrm{a}}$ & & Iris L. & \\
\hline Aristida L. ${ }^{\mathrm{a}, \mathrm{b}}$ & & Itea $\mathrm{L}$. & \\
\hline Artemisia L. & & Lespedeza Michx. & $\mathrm{X}$ \\
\hline Arundinaria Michx ${ }^{a}$ & & Liquidambar L. & \\
\hline Asclepias L. & $\mathrm{X}$ & Lyonia Nutt. & \\
\hline Aster L. & $\mathrm{X}$ & Magnolia L. a & \\
\hline Baptisia Vent. & & Morella Lour. & $\mathrm{X}$ \\
\hline Bidens L. & $\mathrm{X}$ & Nyssa L. & \\
\hline Carex L. & $\mathrm{X}$ & Parthenocissus Planch. & $\mathrm{X}$ \\
\hline Carya Nutt. & $\mathrm{X}$ & Phytolacca L. & $\mathrm{X}$ \\
\hline Centrosema Benth. & $\mathrm{X}$ & Pinus L. ${ }^{\text {a }}$ & \\
\hline Chamaecrista L. & $\mathrm{X}$ & Pityopsis Nutt. & \\
\hline Clethra L. ${ }^{a}$ & $\mathrm{X}$ & Potentilla L. & $\mathrm{X}$ \\
\hline Clitoria Baill. & & Prunus L. & $\mathrm{X}$ \\
\hline Cnidoscolus Pohl & & Quercus L. ${ }^{\mathrm{a}, \mathrm{b}}$ & \\
\hline Coreopsis L. & $\mathrm{X}$ & Rhus L. & $\mathrm{X}$ \\
\hline Cornus L. & $\mathrm{X}$ & Robinia L. & \\
\hline Crataegus L. & $\mathrm{X}$ & Rubus L. ${ }^{c}$ & $\mathrm{X}$ \\
\hline Cyrilla L. & $\mathrm{X}$ & Sassafras Presl. & $\mathrm{X}$ \\
\hline Desmodium Desv. & $\mathrm{X}$ & Silphium L. & $\mathrm{X}$ \\
\hline Dichanthelium Gould & & Smilax L. ${ }^{\mathrm{c}}$ & $\mathrm{X}$ \\
\hline Dioscorea L. & $\mathrm{X}$ & Solidago L. & $\mathrm{X}$ \\
\hline Diospyros L. & & Stillingia L. & \\
\hline Eupatorium Spreng. & & Symplocos Jacq. & $\mathrm{X}$ \\
\hline Euphorbia Wheeler & & Tephrosia Pers. a & \\
\hline Froelichia Moench & $\mathrm{X}$ & Toxicodendron Mill. & \\
\hline Galactia P. Br. & & Vaccinium L. ${ }^{c}$ & \\
\hline Gaylussacia Kunth a,c & & Viola L. & $\mathrm{X}$ \\
\hline Gelsemium L. & & Vitis L. ${ }^{\mathrm{c}}$ & $\mathrm{X}$ \\
\hline
\end{tabular}

${ }^{\text {a }}$ Genera collectively comprising $>80 \%$ of the detected understory biomass.

${ }^{\mathrm{b}}$ Genera collectively comprising $>50 \%$ of the detected understory biomass.

${ }^{\mathrm{c}}$ Primary genera detected producing fruit in the understory.

wood than in dormant-season and growing-season burned upland pine (Table 3, Figure 2). Deer-selected forages increased with years-since-fire in upland hardwood and decreased with years-since-fire in upland pine burned during the growing season (Figure 2).

\section{Fruit Density}

The sum of fruit densities detected across the months was two to three times greater in upland hardwood than in other vegetation types over the course of the growing season (Table 4, Figure 3). Fruit density was similar among vegetation types in June, greatest in dormant season burned upland pine in July, greatest in upland hardwood in August, and greatest in upland and bottomland hardwood vegetation types in September (Table 4, Figure 3). Moreover, $94 \%$ of the fruit detected in growing-season burned upland pine occurred in the last year of the rotation, whereas $6 \%$ oc- 
Table 2. Parameter estimates of generalized linear regression for understory leafy biomass $\left(\mathrm{kg} \mathrm{ha}^{-1}\right)$ in major forest types and as related to years-since-fire in growing season burned longleaf pine forests at Fort Bragg Military Installation, North Carolina, USA, in June to September, 2011 to 2012.

\begin{tabular}{|c|c|c|c|c|c|}
\hline Term & Biomass & Estimate & SE & Chi square & $P$ value \\
\hline Intercept & & 4.33 & 0.01 & 580622.56 & $<0.0001$ \\
\hline Bottomland hardwood & 840 & 1.27 & 0.16 & 64.05 & $<0.0001$ \\
\hline Dormant upland pine & 623 & 2.71 & 0.25 & 116.68 & $<0.0001$ \\
\hline Growing upland pine & 562 & 1.51 & 0.51 & 8.79 & 0.003 \\
\hline Upland hardwood $^{\mathrm{a}}$ & 401 & & & & \\
\hline Same yr as fire & 357 & -2.21 & 0.36 & 37.61 & $<0.0001$ \\
\hline $1 \mathrm{yr}$ post fire & 443 & -1.52 & 0.43 & 12.59 & 0.0004 \\
\hline $2 \mathrm{yr}$ post fire & 636 & 1.31 & 0.40 & 10.70 & 0.001 \\
\hline 3 yr post fire ${ }^{a}$ & 462 & & & & \\
\hline Dormant upland pine* same yr as fire & 396 & 3.15 & 0.19 & 266.21 & $<0.0001$ \\
\hline Dormant upland pine* 1 yr post fire & 733 & 3.77 & 0.20 & 351.56 & $<0.0001$ \\
\hline Dormant upland pine $* 2$ yr post fire & 698 & 3.98 & 0.26 & 243.11 & $<0.0001$ \\
\hline Dormant upland pine $* 3$ yr post fire & 566 & 3.47 & 0.39 & 79.61 & $<0.0001$ \\
\hline Growing upland pine* same year as fire & 553 & 3.66 & 0.32 & 131.83 & $<0.0001$ \\
\hline Growing upland pine* 1 yr post fire & 550 & 4.10 & 0.45 & 83.12 & $<0.0001$ \\
\hline Growing upland pine $* 2$ yr post fire & 722 & 3.30 & 0.37 & 81.61 & $<0.0001$ \\
\hline Growing upland pine*3 yr post fire & 484 & 0.65 & 0.26 & 6.29 & 0.01 \\
\hline Upland hardwood*same year as fire & 322 & & & & \\
\hline Upland hardwood*1 yr post fire ${ }^{a}$ & 345 & & & & \\
\hline Upland hardwood $* 2$ yr post fire ${ }^{\mathrm{a}}$ & 486 & & & & \\
\hline Upland hardwood*3 yr post fire ${ }^{a}$ & 432 & & & & \\
\hline
\end{tabular}

${ }^{a}$ Reference group for comparisons.

curred the year after fire, and no fruits were detected in the same year as fire.

\section{DISCUSSION}

Variation in years-since-fire yields heterogeneity in wildlife food availability across the landscape. For example, we detected no fruits in the same growing season as fire, very few the following growing season, and many in the last year of the three-year prescribed burning rotation. Therefore, shortening the fire-return interval to every one or two years across the landscape may eliminate understory fruit production, which would negatively affect wildlife populations that consume fruits (Woinarski and Legge 2013) or preclude the use of the areas by mobile species (Buler et al. 2007). Alternatively, shorter fire-return intervals yielded more deer-selected forages, although deer may be negatively affected by the lack of cover soon after fire (Lashley et al. 2015b). Additionally, short fire-return intervals maintain grass- and herbaceous-dominated understories by suppressing woody encroachment (White et al. 1990, Glitzenstein et al. 2003). Hence, fire-return interval can be adjusted to encourage the understory structure and composition desired by the landowner (White et al. 1990, Palik et al. 2002, Glitzenstein et al. 2003, Lashley et al. 2014a). On federally owned properties mandated to take an ecosystem-based management approach (e.g., Fort Bragg), we suggest that fire frequencies should be variable. For example, one- to two-year fire-return intervals could be used in some units to encourage herbaceous plants, whereas $\geq 3$ yr fire-return intervals could be used in oth- 


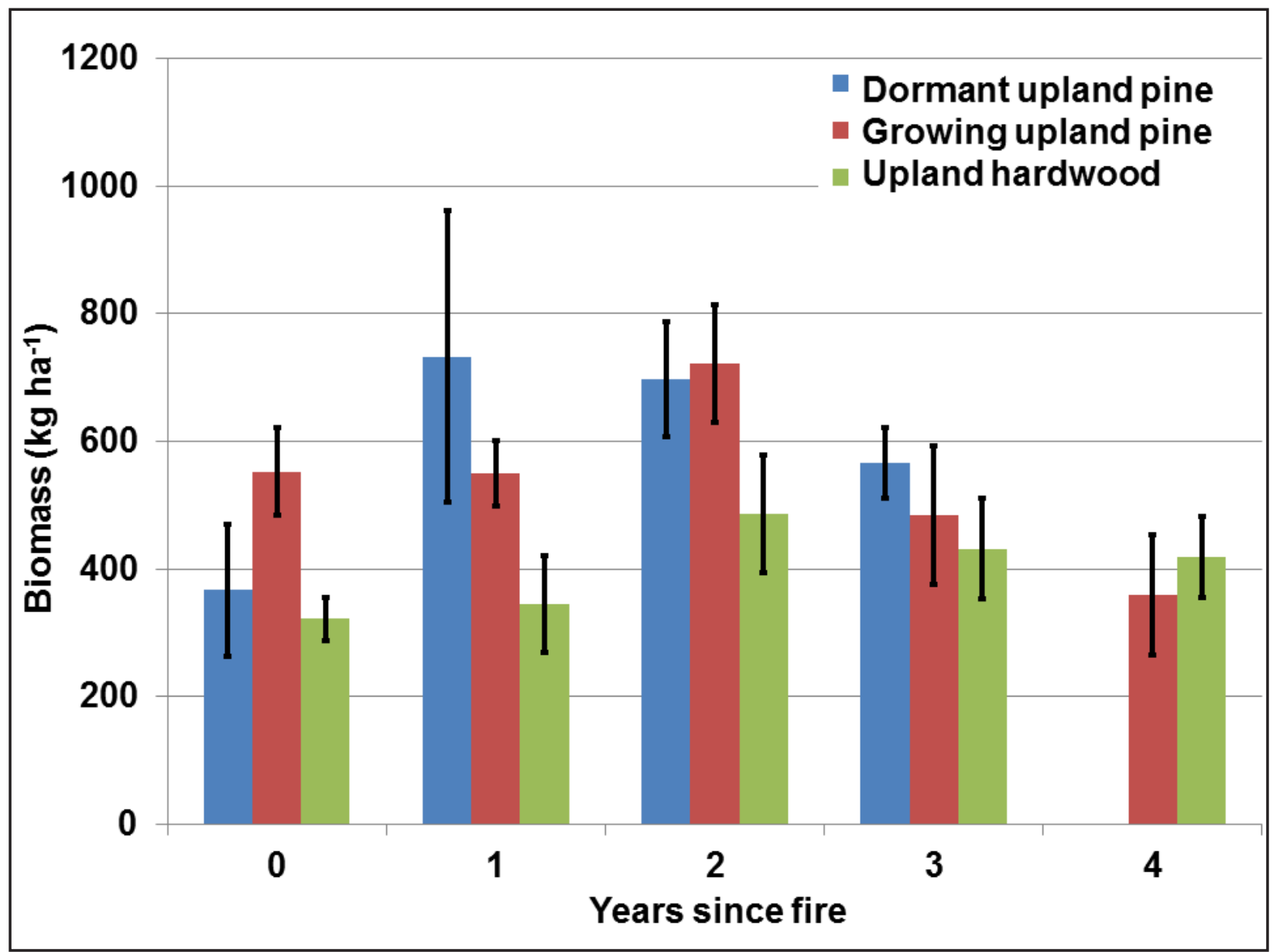

Figure 1. Influence of years-since-fire on understory leafy biomass $\left(\mathrm{kg} \mathrm{ha}^{-1}\right.$; SE) available in the upland longleaf pine vegetation type following dormant- and growing-season fires and in the upland hardwood vegetation type following growing-season fires at Fort Bragg Military Installation, North Carolina, USA in August 2011 and 2012. In each year, 80 plots (40 caged and 40 uncaged) were sampled in each vegetation type with 20 sampled in each years-since-fire category.

er units to encourage fruit production and increased understory leafy biomass (Ostertag and Menges 1994).

Similarly, application of fire within only a single season (e.g., growing season) will fail to promote the maximum floral diversity and fleshy fruit production on the landscape (Hiers et al. 2000, Palik et al. 2002, Ryan et al. 2013). Fire timing plays a key role in flowering synchrony and duration and differentially affects leguminous forbs and other flowering plants with divergent flowering phenologies (Platt et al. 1988, Howe 1994, Hiers et al. 2000). In our study, fruit density after growing- and dormant-season fires followed different trends month to month because of differences in fruiting phenology of the flora responding to each season of fire. Furthermore, growing-season fires promoted a grass-dominated understory (wiregrass in particular), whereas dormant-season fires promoted other herbaceous and woody flora. Therefore, varying fire season across an area is necessary to encourage heterogeneity in understory structure and to provide fruits in every month of the growing season across the landscape (Lashley et al. 2014a).

Although oaks are important for wildlife in the LLPE (Perkins et al. 2008), aggressive removal of oaks has become a primary manage- 
Table 3. Parameter estimates of generalized linear regression for selected deer forage $\left(\mathrm{kg} \mathrm{ha}^{-1}\right)$ in major forest types and as related to years-since-fire in growing season burned longleaf pine forests at Fort Bragg Military Installation, North Carolina, USA, from June to September, 2011 to 2012.

\begin{tabular}{|c|c|c|c|c|c|}
\hline Term & Biomass & Estimate & SE & Chi square & $P$-value \\
\hline Intercept & & 1.11 & 0.04 & 807.49 & $<0.001$ \\
\hline Bottomland hardwood & 84 & 11.55 & 0.49 & 559.06 & $<0.001$ \\
\hline Dormant upland pine & 23 & -20.53 & 0.78 & 689.25 & $<0.001$ \\
\hline Growing upland pine & 28 & -27.61 & 2.77 & 99.43 & $<0.001$ \\
\hline Upland hardwood $^{\mathrm{a}}$ & 44 & & & & \\
\hline Same year as fire & 22 & -34.69 & 2.77 & 157.28 & $<0.001$ \\
\hline $1 \mathrm{yr}$ post fire & 17 & -19.16 & 2.00 & 91.61 & $<0.001$ \\
\hline 2 yr post fire & 28 & -16.21 & 1.44 & 126.10 & $<0.001$ \\
\hline 3 yr post fire & 47 & & & & \\
\hline Dormant upland pine*same year as fire & 16 & 19.17 & 1.62 & 140.91 & $<0.001$ \\
\hline Dormant upland pine*1 yr post fire & 16 & 9.41 & 1.15 & 67.43 & $<0.001$ \\
\hline Dormant upland pine $* 2$ yr post fire & 33 & 17.00 & 1.14 & 221.64 & $<0.001$ \\
\hline Dormant upland pine*3 yr post fire & 26 & -7.17 & $1.21 \mathrm{E}-07$ & $3.54 \mathrm{E}+15$ & $<0.001$ \\
\hline Growing upland pine*same yr as fire & 48 & 32.23 & 2.29 & 198.37 & $<0.001$ \\
\hline Growing upland pine* 1 yr post fire & 25 & 24.90 & 2.52 & 97.71 & $<0.001$ \\
\hline Growing upland pine $* 2$ yr post fire & 32 & 20.52 & 1.96 & 109.25 & 0.1171 \\
\hline Growing upland pine $* 3$ yr post fire & 9 & -2.30 & 1.47 & 2.46 & $<0.001$ \\
\hline Upland hardwood*same year as fire ${ }^{a}$ & 2 & & & & \\
\hline Upland hardwood*1 yr post fire ${ }^{a}$ & 10 & & & & \\
\hline Upland hardwood $* 2$ yr post fire ${ }^{a}$ & 17 & & & & \\
\hline Upland hardwood*3 yr post fire ${ }^{a}$ & 83 & & & & \\
\hline
\end{tabular}

${ }^{a}$ Reference group for comparisons.

ment strategy in the LLPE, with the primary goal to improve habitat for the Endangered Species Act-listed red-cockaded woodpecker (Cantrell et al. 1995, Hiers et al. 2014). Other studies (i.e., Perkins et al. 2008, Hiers et al. 2014, Lashley et al. 2014a) have outlined the direct importance of oaks for food and cover in the LLPE, but our data indicate that hardwoods have an additional indirect benefit through the promotion of understory fruit and selected deer forages. In upland hardwood communities, the sparse distribution of pyrophytic fuels (i.e., wiregrass and longleaf pine needles) may result in a more heterogeneous fire mosaic than typically occurs following prescribed fires in upland pine vegetation types (Kane 2008, Ellair and Platt 2013). The meandering fires in upland hardwood vegetation types likely protect some stems of fruiting understory plants from top-kill, sustaining fruit production even in the same year of fire. As a result, upland hardwood vegetation types provided two to three times more fruit than any other vegetation type during the summer months. Therefore, upland hardwoods provide many benefits to wildlife in the LLPE beyond hard mast production; therefore, removal efforts should be minimized when wildlife habitat is of concern (Perkins et al. 2008, Hiers et al. 2014, Lashley et al. 2014a).

Like wildlife foods, cover should be considered when managing plant communities with prescribed fire. Prescribed fire greatly influences understory structure as it relates to wildlife cover (McCord et al. 2014), which inevitably influences the overall quality of an area as habitat for a given species. In fact, cover may be the more important resource in habitat selection as indicated in two concurrent studies at Fort Bragg that demonstrated that 


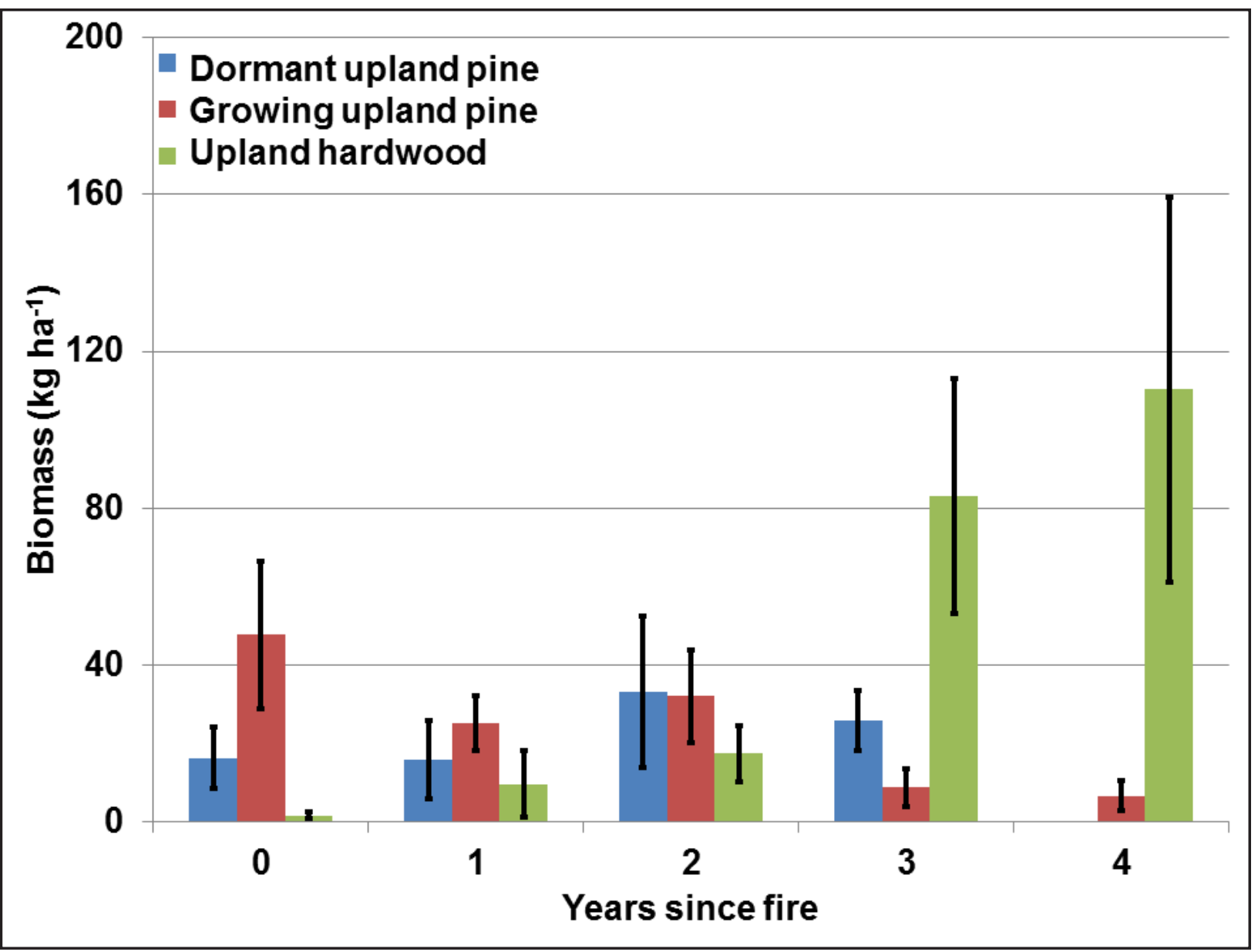

Figure 2. Influence of years-since-fire on understory leafy biomass $\left(\mathrm{kg} \mathrm{ha}^{-1}\right.$; SE) of plants selected by white-tailed deer in the upland longleaf pine vegetation type following dormant- and growing-season fires and in the upland hardwood vegetation type following growing-season fires at Fort Bragg Military Installation, North Carolina, USA, in August 2011 and 2012. In each year, 80 plots (40 caged and 40 uncaged) were sampled in each vegetation type with 20 sampled in each year-since-fire category.

deer increasingly selected burned areas as years-since-fire increased (Lashley et al. $2015 b$ ) and wild turkeys selected burned areas following dormant-season fires (Kilburg et al. 2015). Kilburg et al. (2015) and Lashley et al. (2015b) suggested that cover was the primary resource (as opposed to food) driving the selection of areas, despite the increased energy requirements of reproduction during the respective study periods. Our results for understory biomass following fire support this previous work because the biomass likely serves as a proxy for the availability of cover. Thus, a matrix of shorter and longer years-since-fire may be important to ensure adequate availability of food and cover simultaneously.

We suggest that a variety of strategies can be used to promote fire-influenced heterogeneity in fire-maintained systems. Heterogeneity can be maintained at the landscape level by varying fire season, frequency, and intensity among burn units (Fuhlendorf and Engle 2001, Fuhlendorf et al. 2006). Within a burn unit, temporal heterogeneity can be encouraged by varying the time between fires, the season of subsequent fires, and the firing techniques and firing conditions used for each prescribed burn when possible (Cheney et al. 1993). Addition- 
Table 4. Parameter estimates of generalized linear regression for summer fruit density (fruits ha-1) in major forest types and as related to years-since-fire in longleaf pine stands burned during the growing season at Fort Bragg Military Installation, North Carolina, USA in June to September, 2011 to 2012.

\begin{tabular}{lrrrrr}
\hline \multicolumn{1}{c}{ Term } & Mean & Estimate & SE & $\begin{array}{c}\text { Wald } \\
\text { Chi square }\end{array}$ & $\begin{array}{c}\text { Prob }> \\
\text { Chi square }\end{array}$ \\
\hline Intercept & & 1.41 & 0.09 & 258.48 & $<0.0001$ \\
Bottomland hardwood & 2324 & -5.79 & 0.61 & 89.43 & $<0.0001$ \\
Dormant upland pine & 3584 & -5.17 & 0.74 & 2.49 & 0.1144 \\
Growing upland pine & 2312 & -5.20 & 0.56 & 87.74 & $<0.0001$ \\
Upland hardwood & 5440 & & & & \\
June & 548 & -12.00 & 2.06 & 34.05 & $<0.0001$ \\
July & 3988 & -0.46 & 0.71 & 0.42 & 0.5146 \\
August & 2572 & -2.06 & 0.64 & 10.33 & 0.0013 \\
September & 6548 & & & & \\
Bottomland hardwood*June & 947 & -0.27 & 1.34 & 0.04 & 0.8405 \\
Bottomland hardwood*July & 1240 & -6.57 & 0.71 & 85.94 & $<0.0001$ \\
Bottomland hardwood*august & 631 & -9.94 & 0.93 & 113.89 & $<0.0001$ \\
Dormant upland pine*June & 448 & 2.85 & 1.91 & 2.23 & 0.1351 \\
Dormant upland pine*July & 6712 & 1.17 & 0.54 & 4.70 & 0.0302 \\
Dormant upland pine*August & 1080 & -4.15 & 0.78 & 28.50 & $<0.0001$ \\
Growing upland pine*June & 503 & 0.68 & 1.51 & 0.20 & 0.6525 \\
Growing upland pine*July & 2833 & -4.53 & 0.58 & 61.00 & $<0.0001$ \\
Growing upland pine*August & 567 & -9.07 & 0.83 & 117.97 & $<0.0001$ \\
Upland hardwood*June & 307 & & & & \\
Upland hardwood*July & 4813 & & & & \\
Upland hardwood*August & 8027 & & & & \\
Same yr as fire & 0 & -43.02 & 2.59 & 275.58 & $<0.0001$ \\
1 yr post fire & 220 & -15.68 & 2.75 & 32.51 & $<0.0001$ \\
2 yr post fire & 3367 & & & & \\
\hline & & & & & \\
\hline a & & & & &
\end{tabular}

${ }^{a}$ Reference group for comparisons.

ally, in the LLPE, some upland hardwood should be allowed to persist because of the inherent heterogeneity of post-fire understory conditions and continuous availability of fleshy fruit and hard mast that may otherwise be lost (Hiers et al. 2014, Lashley et al. 2014a). Furthermore, fires allowed to burn into drainages generally will be suppressed by high moisture levels; at Fort Bragg, these less frequently burned drainages contained unique plant assemblages and abundant fruits early and late in the growing season. We recommend that managers randomly assign a fire prescription (i.e., stochastic variability in firing techniques, season, return frequency, fire intensity, and weather conditions) to each burn block to maximize structural and floral diversity. In fact, Robbins and Meyers (1992) developed a matrix that managers in the LLPE could use to select random fire seasons and frequencies for each burn unit, which they said was supported by historical accounts of fire conditions in the LLPE ecosystem (Frost 1993). For example, it is believed that $\sim 70 \%$ of fires occurred during the growing season based on the historical distribution of lightning-ignited fires (Fill et al. 2012) and that fire-return intervals in upland pine forests ranged from biannual to every 12 years (Stambaugh et al. 2011). Randomly assigning treat- 


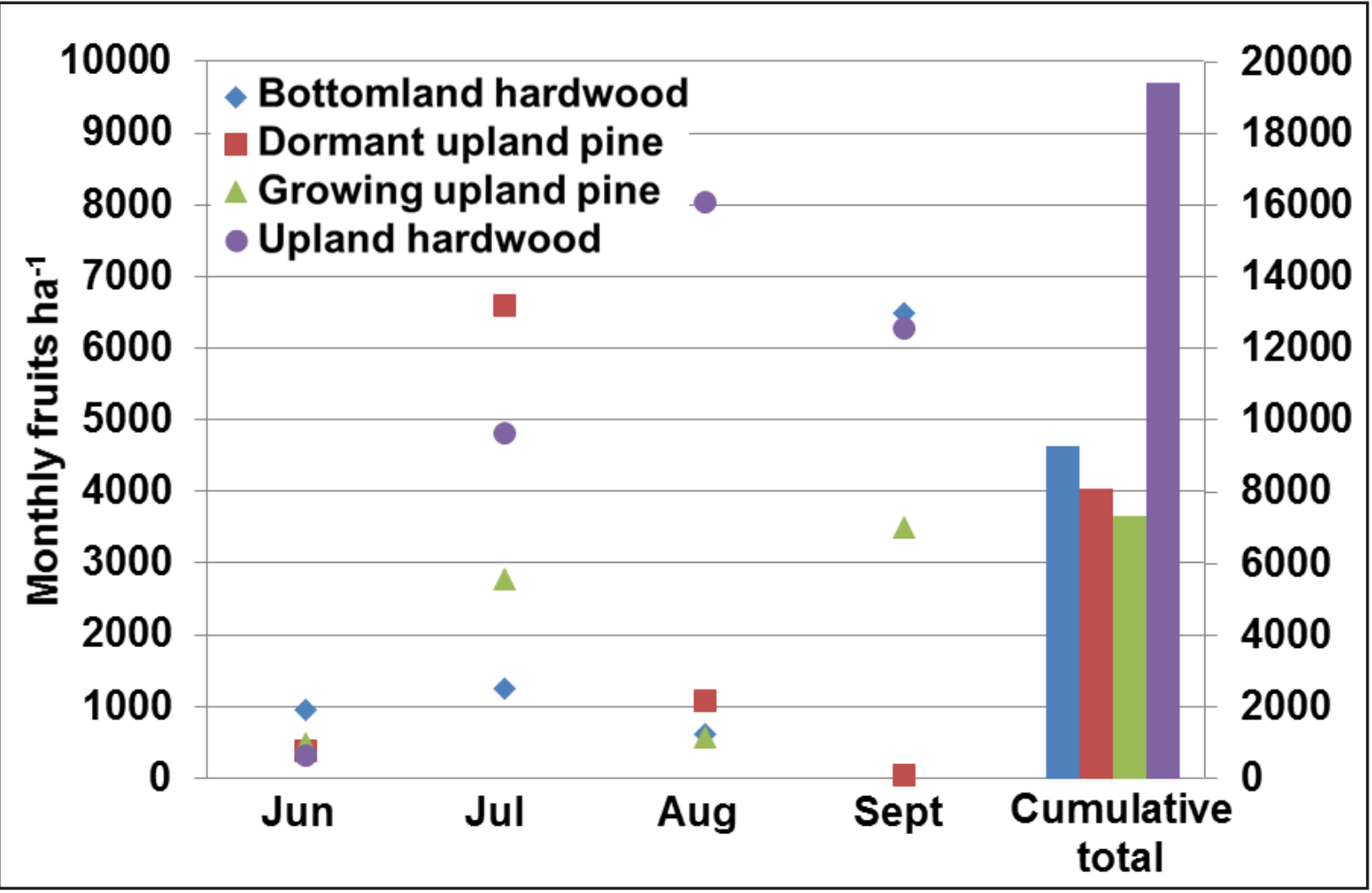

Figure 3. Mean fruit produced (fruits $\mathrm{ha}^{-1}$; SE) during each summer month (symbols) and cumulative fruit produced (fruits ha ${ }^{-1}$; bars) in the bottomland hardwood vegetation type, following dormant- and growing-season fires in the upland pine vegetation type, and following growing-season fires in the upland hardwood vegetation type at Fort Bragg Military Installation, North Carolina, USA, in August 2011 and 2012. In each month of each year, 30 transects were sampled in each vegetation type.

ments with parameters guided by literature and ongoing research will more likely restore and maintain the heterogeneous forest structure and floral and faunal composition of the LLPE and other fire-maintained forest ecosystems (Greenberg 2001, Bond and Archibald 2003, Lashley et al. 2014a).

\section{ACKNOWLEDGEMENTS}

We thank the United States Department of Defense and Fort Bragg Military Installation for financial contributions to this research. We thank A. Schultz, J. Jones, and the Fort Bragg Wildlife Branch for technical and logistical support. Special thanks to J. Thompson for statistical consultation. Also, we thank A. Prince, M. Elfelt, E. Kilburg, B. Sherrill, and M. Broadway for assistance in data collection and entry.

\section{LITERATURE CITED}

Aschenbach, T.A., B.L. Foster, and D.W. Imm. 2010. The initial phase of a longleaf pine-wiregrass savanna restoration: species establishment and community responses. Restoration Ecology 18: 762-771. doi: 10.1111/j.1526-100X.2009.00541.x 
Beckage, B., W.J. Platt, and B. Panko. 2005. A climate-based approach to the restoration of fire-dependent ecosystems. Restoration Ecology 13: 429-431. doi: 10.1111/j.1526-100X.2005.00070.x

Bond, W.J., and S. Archibald. 2003. Confronting complexity: fire policy choices in South African parks. International Journal of Wildland Fire 12: 381-389. doi: 10.1071/WF03024

Brockway, D.G., K.W. Outcalt, D.J. Tomczak, and E.E. Johnson. 2005. Restoration of longleaf pine ecosystems. USDA Forest Service General Technical Report SRS-89, Southern Research Station, Asheville, North Carolina, USA.

Buler, J.J., F.R. Moore, and S. Woltmann. 2007. A multi-scale examination of stopover habitat use by birds. Ecology 88: 1789-1802. doi: 10.1890/06-1871.1

Cantrell, M.A., J.J. Brithcher, and E.L. Hoffman. 1995. Red-cockaded woodpecker management initiatives at Fort Bragg Military Installation. Pages 89-97 in: D. L. Kulhavy, R.G. Hooper, and R. Costa, editors. Red-cockaded woodpecker: recovery, ecology and management. Center for Applied Studies in Forestry, College of Forestry, Stephen F. Austin State University, Nacodoches, Texas, USA.

Cheney, N.P., J.S. Gould, and W.R. Catchpole. 1993. The influence of fuel, weather and fire shape variables on fire-spread in grasslands. International Journal of Wildland Fire 3: 31-44. doi: 10.1071/WF9930031

Chesson, J. 1978. Measuring preference in selective predation. Ecology 59: 211-215. doi: $10.2307 / 1936364$

Chesson, J. 1983. The estimation and analysis of preference and its relationship to foraging models. Ecology 64: 1297-1304. doi: 10.2307/1937838

Chitwood, M.C., M.A. Lashley, J.C. Kilgo, C.E. Moorman, and C.S. DePerno. 2015a. Whitetailed deer population dynamics and adult female survival in the presence of a novel predator. Journal of Wildlife Management 79: 211-219. doi: 10.1002/jwmg.835

Chitwood, M.C., M.A. Lashley, J.C. Kilgo, K.H. Pollock, C.E. Moorman, and C.S. DePerno. 2015b. Do biological and bedsite characteristics influence survival of neonatal white-tailed deer? PLoS ONE 10(3): e0119070. doi: 10.1371/journal.pone.0119070

Chitwood, M.C., M.A. Lashley, C.E. Moorman, and C.S. DePerno. 2014. Confirmation of coyote predation on adult female white-tailed deer in the southeastern US. Southeastern Naturalist 13: N30-N32.

Clewell, A.F. 1989. Natural history of wiregrass (Aristida stricta Michx., Gramineae). Natural Areas Journal 9: 223-233.

Côté, S.D., T.P. Rooney, J.P. Tremblay, C. Dussault, and D.M. Waller. 2004. Ecological impacts of deer overabundance. Annual Review of Ecology, Evolution, and Systematics 35: 113-147. doi: 10.1146/annurev.ecolsys.35.021103.105725

Drew, M.B., L.K. Kirkman, and A.K. Gholson. 1998. The vascular flora of Ichauway, Baker County, Georgia: a remnant longleaf pine/wiregrass ecosystem. Castanea 63: 1-24.

Ellair, D.P., and W.J. Platt. 2013. Fuel composition influences fire characteristics and understory hardwoods in pine savanna. Journal of Ecology 101: 192-201. doi: 10.1111/1365-2745. 12008

Fill, J.M., S.M. Welch, J.L. Waldron, and T.A. Mousseau. 2012. The reproductive response of an endemic bunchgrass indicates historical timing of a keystone process. Ecosphere 3: 1-12. doi: 10.1890/ES12-00044.1

Franklin, J.F. 1993. Preserving biodiversity: species, ecosystems, or landscapes? Ecological Applications 3: 202-205. doi: 10.2307/1941820 
Frost, C.C. 1993. Four centuries of changing landscape patterns in the longleaf pine ecosystem. Proceedings of the Tall Timbers fire ecology conference 18: 17-43.

Frost, C.C. 2006. History and future of the longleaf pine ecosystem. Pages 9-42 in: S. Jose, E.J. Jokela, and D.L. Miller, editors. The longleaf pine ecosystem. Springer, New York, New York, USA. doi: 10.1007/978-0-387-30687-2_2

Fuhlendorf, S.D., and D.M. Engle. 2001. Restoring heterogeneity on rangelands: ecosystem management based on evolutionary grazing patterns. BioScience 51: 625-632. doi: 10.1641/0006-3568(2001)051[0625:RHOREM]2.0.CO;2

Fuhlendorf, S.D., W.C. Harbell, D.M. Engle, R.G. Hamilton, C.A. Davis, and D.M. Leslie. 2006. Should heterogeneity be the basis for conservation? Grassland bird response to fire and grazing. Ecological Applications 16: 1706-1716. doi: 10.1890/1051-0761(2006)016 [1706:SHBTBF]2.0.CO;2

Glitzenstein, J.S., D.R. Streng, and D.D. Wade. 2003. Fire frequency effects on longleaf pine (Pinus palustris) vegetation in South Carolina and northeast Florida, USA. Natural Areas Journal 23: 22-37.

Greenberg, C.H. 2001. Fire, habitat structure, and herpetofauna in the Southeast. Pages 91-99 in: W.M. Ford, K.R. Russell, C.E. Moorman, editors. The role of fire in nongame wildlife management and community restoration: traditional uses and new directions. USDA Forest Service General Technical Report NE-288, Southern Research Station, Asheville, North Carolina, USA.

Greenberg, C.H., D.J., Levey, C. Kwit, J.P. Mccarty, S.F. Pearson, S. Sargent, and J. Kilgo. 2012. Long-term patterns of fruit production in five forest types of the South Carolina upper coastal plain. Journal of Wildlife Management 76: 1036-1046. doi: 10.1002/jwmg.343

Hiers, J.K., R.J. Mitchell, L.R., Boring, J.J. Hendricks, and R. Wyatt. 2003. Legumes native to longleaf pine savannas exhibit capacity for high $\mathrm{N}_{2}$-fixation rates and negligible impacts due to timing of fire. New Phytologist 157: 327-338. doi: 10.1046/j.1469-8137.2003.00679.x

Hiers, J.K., J.R. Walters, R.J. Mitchell, J.M. Varner, L.M. Conner, L.A. Blanc, and J. Stowe. 2014. Ecological value of retaining pyrophytic oaks in longleaf pine ecosystems. The Journal of Wildlife Management 78: 383-393. doi: 10.1002/jwmg.676

Hiers, J.K., R. Wyatt, and R.J. Mitchell. 2000. The effects of the fire regime on legume reproduction in longleaf pine savannas: is a season selective? Oecologia 125: 521-530. doi: $10.1007 / \mathrm{s} 004420000469$

Howe, H.F. 1994. Response of early- and late-flowering plants to fire season in experimental prairies. Ecological Applications 4: 121-133. doi: 10.2307/1942122

Kane, J.M., J.M. Varner, and J.K. Hiers. 2008. The burning characteristics of southeastern oaks: discriminating fire facilitators from fire impeders. Forest Ecology and Management 256: 2039-2045. doi: 10.1016/j.foreco.2008.07.039

Kilburg, E.L., C.E. Moorman, C.S. DePerno, D. Cobb, and C.A. Harper. 2015. Wild turkey prenesting-resource selection in a landscape managed with frequent prescribed fire. Southeastern Naturalist 14: 137-146. doi: 10.1656/058.014.0114

Landers, J.L., D.H. Van Lear, and W.D. Boyer. 1995. The longleaf pine forests of the southeast: requiem or renaissance? Journal of Forestry 93: 39-44.

Lashley, M.A., M.C. Chitwood, C.S. DePerno, and C.E. Moorman. 2014b. Collection, handling, and analysis of forages for concentrate selectors. Wildlife Biology in Practice 10: 6-15. doi: 10.2461/wbp.2014.10.2 
Lashley, M.A., M.C. Chitwood, C.A. Harper, C.E. Moorman, and C.S. DePerno. 2015a. Poor soils and density-mediated body weight in deer: forage quality or quantity? Wildlife Biology 21(4): 213-219. doi: 10.2981/wlb.00073

Lashley, M.A., M.C. Chitwood, R. Kays, C.A. Harper, C.S. DePerno, and C.E. Moorman. $2015 b$. Prescribed fire affects female white-tailed deer habitat use during summer lactation. Forest Ecology and Management 348: 220-225. doi: 10.1016/j.foreco.2015.03.041

Lashley, M.A., M.C. Chitwood, A. Prince, M. Elfelt, E. Kilburg, C.S. DePerno, and C.E. Moorman. 2014a. Subtle effects of a managed fire regime: a case study in the longleaf pine ecosystem. Ecological Indicators 38: 212-217. doi: 10.1016/j.ecolind.2013.11.006

Lashley, M.A., and C.A. Harper. 2012. The effects of extreme drought on native forage nutritional quality and white-tailed deer diet selection. Southeastern Naturalist 11: 699-710. doi: 10.1656/058.011.0409

Lashley, M.A., C.A. Harper, G.E. Bates, and P.D. Keyser. 2011. Forage availability for whitetailed deer following silvicultural treatments in hardwood forests. Journal of Wildlife Management 75: 1467-1476. doi: 10.1002/jwmg. 176

Lashley, M.A., J.R. Thompson, M.C. Chitwood, C.S. DePerno, and C.E. Moorman. 2014c. Evaluation of methods to estimate understory fruit biomass. PloS ONE 9(5): e96898. doi: 10.1371/journal.pone.0096898

Leslie Jr., D.M., M. Vavra, E.E. Starkey, and R.C. Slater. 1983. Correcting for differential digestibility in microhistological analyses involving common coastal forages of the Pacific Northwest. Journal of Range Management 36: 730-732. doi: 10.2307/3898197

McCord, J.M., C.A. Harper, and C.H. Greenberg. 2014. Brood cover and food resources for wild turkeys following silvicultural treatments in mature upland hardwoods. Wildlife Society Bulletin 38: 265-272. doi: 10.1002/wsb.403

Ostertag, R., and E.S. Menges. 1994. Patterns of reproductive effort with time since last fire in Florida scrub plants. Journal of Vegetation Science 5: 303-310. doi: 10.2307/3235853

Palik, B.J., R.J. Mitchell, and J.K. Hiers. 2002. Modeling silviculture after natural disturbance to sustain biodiversity in the longleaf pine (Pinus palustris) ecosystem: balancing complexity and implementation. Forest Ecology and Management 155: 347-356. doi: 10.1016/ S0378-1127(01)00571-0

Perkins, M.W., L.M. Conner, and M.B. Howze. 2008. The importance of hardwood trees in the longleaf pine forest ecosystem for Sherman's fox squirrels. Forest Ecology and Management 255: 1618-1625. doi: 10.1016/j.foreco.2007.11.020

Platt,W.J., G.W. Evans, and M.M. Davis. 1988. Effects of fire season on flowering of forbs and shrubs in longleaf pine forests. Oecologia 76: 353-363. doi: 10.1007/BF00377029

Robbins, L.E., and R.L. Myers. 1992. Seasonal effects of prescribed burning in Florida: a review. Miscellaneous Publication 8, Tall Timbers, Tallahassee, Florida, USA.

Ryan, K.C., E.E. Knapp, and J.M. Varner. 2013. Prescribed fire in North American forests and woodlands: history, current practice, and challenges. Frontiers in Ecology and Environment 11: e15-e24. doi: 10.1890/120329

Sorrie, B.A., J.B. Gray, and P.J. Crutchfield. 2006. The vascular flora of the longleaf pine ecosystem of Fort Bragg and Weymouth Woods, North Carolina. Castanea 71: 129-161. doi: 10.2179/05-02.1

Stambaugh, M.C., R.P. Guyette, and J.M. Marschall. 2011. Longleaf pine (Pinus palustris Mill.) fire scars reveal new details of a frequent fire regime. Journal of Vegetation Science 22: 1094-1104. doi: 10.1111/j.1654-1103.2011.01322.x 
Streng, D.R., J.S. Glitzenstein, and W.J. Platt. 1993. Evaluating season of burn in longleaf pine forests: a critical literature review and some results from an ongoing long-term study. Proceedings of the Tall Timbers Fire Ecology Conference 18: 227-263.

Van Lear, D.H., and R.F. Harlow. 2000. Fire in the eastern United States: influence on wildlife habitat. Pages 2-10 in: W.M. Ford, K.R. Russell, C.E. Moorman, editors. The role of fire in nongame wildlife management and community restoration: traditional uses and new directions. USDA Forest Service General Technical Report NE-288, Southern Research Station, Asheville, North Carolina, USA.

Vavra, M., and J.L. Holechek. 1980. Factors influencing microhistological analysis of herbivore diets. Journal of Range Management 33: 371-374. doi: 10.2307/3897886

Waldrop, T.A., D.L. White, and S.M. Jones. 1992. Fire regimes for pine-grassland communities in the southeastern United States. Forest Ecology and Management 47: 195-210. doi: 10.1016/0378-1127(92)90274-D

White, D.L., T.A. Waldrop, and S.M. Jones. 1990. Forty years of prescribed burning on the Santee fire plots: effects on understory vegetation. USDA Forest Service General Technical Report SE-69, Southern Research Station, Asheville, North Carolina, USA.

Woinarski, J.C.Z., and S. Legge. 2013. The impacts of fire on birds in Australia's tropical savannas. Emu 113: 319-352. doi: 10.1071/MU12109 